\title{
Water quality alteration sources along the Lenguazaque River (Colombia): integrating chemistry and $\mathrm{Pb}$ isotopes
}

\author{
DAVID WIDORY ${ }^{1}$, CARME HUGUET ${ }^{2}$, JILLIAN \\ PEARSE $^{3}$, AlbA AVILA ${ }^{4}$
}

${ }^{1}$ UQAM, Montreal, Canada, widory.david@uqam.ca

${ }^{2}$ Los Andes University, Bogotá, Colombia, m.huguet@uniandes.edu.co

${ }^{3}$ Los Andes University, Bogotá, Colombia, j.pearse@uniandes.edu.co

${ }^{4}$ Los Andes University, Bogotá, Colombia, aavila@uniandes.edu.co

Colombia's water natural resources are undergoing increasing pressure related to the country's urbanisation, increased industrial activity, mining and agriculture. The anthropogenic environmental impact, notably from the coal industry, has thus become a critical issue. The study area is located in Cundinamarca, the department with the highest number of mining licenses and which produces $3 \%$ of the national coal. Lenguazaque has the second highest coal production in the department, and in addition to extraction, also produces coke. Although modern and advanced mining companies are established in the area, $44 \%$ of mining sites operate without environmental licenses. Most of these are artisanal, small-scale and operating in illegal extraction locations. Here we are presenting a study coupling classical geochemistry and the lead $(\mathrm{Pb})$ isotope systematic to assess the potential contribution of coal mining exhausts to the degradation of water quality along the Lenguazaque River. To fulfill this obejctive we sampled and characterised sediment, soil and coal samples along the river and its main tributaries. Results indicate that while natural water rock interaction (WRI) provides $\mathrm{Pb}$ to the river, its concentrations constantly increase along the stream. Each of these increase steps can be isotopically linked to inputs from coal mines operating along the river and, to a lesser extent, to the urban effluents from the town of Lenguazaque. 